\title{
Isolation, Characterization and Antifungal Activity of Major Constituents of the Himalayan Lichen Parmelia reticulata Tayl. $\dagger$
}

\author{
Mayurika Goel, ${ }^{+, \neq}$Prem Dureja, $^{*, \neq}$ Archna Rani, ${ }^{+}$Prem L. Uniyal, ${ }^{\S}$ and Hartmut Laatsch" \\ ${ }^{\dagger}$ Department of Applied Chemistry, Delhi Technological University, Delhi-110042, India \\ ${ }^{\ddagger}$ Division of Agricultural Chemicals, Indian Agricultural Research Institute, New Delhi-110012, India \\ ${ }^{\S}$ Department of Botany, University of Delhi, Delhi-110007, India \\ "Institute of Organic and Biomolecular Chemistry, University of Göttingen, D-37077 Göttingen, Germany
}

Supporting Information

ABSTRACT: Antifungal activity of hexane, ethyl acetate and methanol extracts of Parmelia reticulata was evaluated against soilborne pathogenic fungi, namely, Sclerotium rolfsii, Rhizoctonia solani, R. bataticola, Fusarium udum, Pythium aphanidermatum and $P$. debaryanum by poisoned food technique. Maximum antifungal activity was exhibited by hexane and ethyl acetate extracts against most of the test pathogens. Secondary metabolites, namely, $( \pm)$-isousnic acid, $( \pm)$-protolichesterinic acid, atranorin, evernyl, ethyl hematommate, ethyl orsellinate, methyl hematommate (3-formyl-2,4-dihydroxy-6-methylbenzoic acid methyl ester), 2-hydroxy-4-methoxy-3,6-dimethylbenzoic acid, 1-hydroxy-3,6-dimethoxy-8-methyl-xanthen-9-one, baeomycesic acid and salazinic acid, were isolated from the above extracts and identified by ${ }^{1} \mathrm{H}$ NMR, ${ }^{13} \mathrm{C}$ NMR and mass spectroscopic methods. When these metabolites were tested for antifungal activity against test pathogens, maximum antifungal activity was exhibited by $( \pm)$-protolichesterinic acid against $R$. solani $\left(\mathrm{ED}_{50}=23.09 \mu \mathrm{g} \mathrm{mL}^{-1}\right)$ and $P$. debaryanum $\left(\mathrm{ED}_{50}=16.07 \mu \mathrm{g} \mathrm{mL}^{-1}\right)$ and by atranorin against $S$. rolfsii $\left(\mathrm{ED}_{50}=39.70 \mu \mathrm{g} \mathrm{mL}^{-1}\right)$. The antifungal activity of protolichesterinic acid was found to be comparable to that of hexaconazole, a commercial fungicide.

KEYWORDS: lichens, Parmelia reticulata, antifungal activity, pathogenic fungi, major constituents

\section{INTRODUCTION}

Fungi cause enormous economic loss in agriculture and the food industry by destroying crops in the field and during storage. ${ }^{1,2}$ Among various plant pathogenic fungi, Sclerotium rolfsii Sacc., Rhzoctonia solani J.G.Kuhn., R. bataticola (Taubenh.) E.J. Butler, Fusarium udum Butler, Pythium aphanidermatum (Edson) Fitz. and P. debaryanum Hesse, are devastating soilborne pathogenic fungi with a wide host range. ${ }^{3,4}$ They infect seeds, seedlings, and mature plants in the field causing collar rot, wilt, damping off, dry root rot, etc. ${ }^{5,6}$ A large number of synthetic chemicals used to control these pathogenic fungi are detrimental to the environment and human health and need to be replaced by safe, biodegradable products. Among the various alternatives, natural plant products are gaining momentum and catching the attention of scientists worldwide. ${ }^{7}$ Such products are relatively broad-spectrum, bioefficacious, economical, biodegradable and environmentally safe and can be ideal candidates for use as agrochemicals. ${ }^{8}$

Natural products with diverse bioactivities and structures are an important source of novel chemicals with pharmaceutical potentials. ${ }^{9}$ Lichens, the symbiotic organisms of fungi and algae, are found commonly worldwide and can survive a variety of harsh environmental conditions. Lichens are inherently resistant to microbial infection due to the production of large numbers of unique secondary metabolites. ${ }^{10}$ Their flexibility in habitat enables them to synthesize unique naturally occurring secondary metabolites, which not only are different in their chemical structures but also show differences in their biological activity.
In fact most of their metabolites have already been reported to have manifold biological activity such as antiviral, antibacterial, antifungal, antibiotics, allergenic, antiherbivore, antitumor, plant growth inhibitory and enzyme inhibitory. ${ }^{11,12}$ Parietin, anthraquinone isolated from methanol extract of Caloplaca cerina (Ehrh. ex Hedwig) Th. Fr. (Teloschistaceae), has been reported to have significant antifungal activity. ${ }^{13}$ Extracts of Andean lichens Protousnea poeppigii (Nees \& Flot.) Krog. (Parmeliaceae) and Usnea florida var. rigida Arch. demonstrated antimicrobial activity against the pathogenic fungi Microsporum gypseum, Trichophyton mentagrophytes and T. rubrum. Isodivaricatic acid, 5-propylresorcinol, divaricatinic acid and usnic acid were identified as antifungal agents. ${ }^{14}$ However studies related to their potential use as agrochemicals are very few. In this paper we report the isolation, characterization and in vitro antifungal activity of various solvent extracts and major secondary metabolites isolated from lichen Parmelia reticulata Tayl. against soilborne pathogenic fungi.

\section{MATERIALS AND METHODS}

Chemicals and Reagents. All of the chemicals and reagents used were purchased from Sigma-Aldrich and used without further purification.

Received: October 21, 2010

Accepted: January 27, 2011

Revised: January 27, 2011

Published: February 25, 2011 
Plant Pathogenic Fungi. Plant pathogenic fungi, namely, Sclerotium rolfsii, Rhizoctonia solani, $R$. bataticola, Fusarium udum, Pythium aphanidermatum and $P$. debaryanum were purchased from the Indian Type Culture, Division of Mycology and Plant Pathology, Indian Agricultural Research Institute, New Delhi, India. Pathogenic fungi were maintained on potato dextrose agar (PDA) at $25{ }^{\circ} \mathrm{C}$ and were subcultured on PDA Petri dishes for 5-6 days at $28^{\circ} \mathrm{C}$ prior to use as inoculums.

Lichen. Samples of Parmelia reticulata Tayl. were collected from Kilberi Forest ranges (Northern Himalayas), Uttarakhand, India, and air-dried. A specimen was deposited in the herbarium of the Department of Botany, University of Delhi, Delhi, India.

Chromatography. Thin layer chromatography (TLC) was performed on $20 \mathrm{~cm} \times 20 \mathrm{~cm}$ glass plates coated with $0.5 \mathrm{~mm}$ silica gel G, containing $10 \%$ of gypsum as binder, air-dried, preactivated at $120^{\circ} \mathrm{C}$ for $2 \mathrm{~h}$ before use. The plates were developed in three solvent systems usually employed in the TLC of lichen substances [solvent A: toluenedioxane-acetic acid $(180: 45: 5, \mathrm{v} / \mathrm{v})$; solvent B: hexane-methyl tertbutyl ether-formic acid $(140: 72: 18 \mathrm{v} / \mathrm{v})$; solvent C: toluene-acetic acid $(170: 30, v / v)]$ and visualized by spraying with $10 \%$ sulfuric acid and then heating at $110^{\circ} \mathrm{C}$ in an oven or hot plate for $10 \mathrm{~min}$ to develop the spots. Sulfuric acid charring detects the broadest range of compound types, including virtually all terpenes and phenolic derivatives. After the plates are charred, the compounds give a range of characteristic visible colors and some even have a characteristic fluorescence. The TLC cards used were purchased from Polygram SIL G/UV254 (Macherey-Nagel \& Co., Düren, Germany). Preparative thin layer chromatography (PTLC) was performed by making preparative TLC by adding $55 \mathrm{~g}$ of silica gel P/UV 254 (Macherey-Nagel \& Co.) to $120 \mathrm{~mL}$ of demineralized water with continuous stirring for $15 \mathrm{~min}$ the homogenous suspension $(60 \mathrm{~mL})$ was then evenly distributed on a horizontally held $(20 \times$ $20 \mathrm{~cm}$ ) glass plate. The plates were dried at ambient temperature for $24 \mathrm{~h}$ and activated by heating at $130^{\circ} \mathrm{C}$. Chemical constituents were separated using a glass column $(75 \mathrm{~cm} \times 2 \mathrm{~cm}$ i.d. $)$ packed with preactivated silica gel $(50 \mathrm{~g}, 60-120 \mathrm{mesh})$ in hexane and eluted with a mixture of hexane, hexane and dichloromethane, and dichloromethane and ethyl acetate in different ratios. Different fractions $(25 \mathrm{~mL}$ each) were collected and evaporated to dryness on a water bath. The fractions containing similar compounds (as monitored by TLC) were combined and purified further for characterization.

Instrumentation. ${ }^{1} \mathrm{H}$ NMR and ${ }^{13} \mathrm{C}$ NMR spectra were recorded on a Bruker $400 \mathrm{AC}$ ( 400 and $75.5 \mathrm{MHz}$ ) instrument. The solvents used were deuteriochloroform $\left(\mathrm{CDCl}_{3}\right)$, acetone and DMSO- $d_{6}$ containing tetramethylsilane $\left[\left(\mathrm{CH}_{3}\right)_{4} \mathrm{Si}\right.$, TMS $]$ as the internal standard. All ${ }^{13} \mathrm{C}$ multiplicities were deduced from 90 and $135^{\circ} \mathrm{DEPT}$ experiment. The chemical shift values were recorded on the $\delta$ scale, and the coupling constants $(J)$ are in Hertz. Mass spectra were recorded on a mass spectrometer at $70 \mathrm{eV}$ (Varian MAT 731). High resolution mass were measured with perfluorokerosene as reference. ESI (electron spray ionization mass spectrometry) was performed with a Quattro triplequadrupole mass spectrometer (Finnigan MAT Incos 50).

Extraction and Isolation of Compounds. The lichen thalli were washed thoroughly with water to remove dust particles and dried at room temperature. The air-dried mass was powdered with a mortar and pestle. The powdered material $(50 \mathrm{~g})$ was extracted in a Soxhlet extractor with hexane followed by ethyl acetate and finally with methanol $(500 \mathrm{~mL})$ for $6 \mathrm{~h}$. The solvent was evaporated in vacuo, and the dried residue obtained was stored at $4{ }^{\circ} \mathrm{C}$ for further biological screening. The above solvent extracts were subjected to column chromatography and compounds I to XI were isolated. The structures of these compounds were analyzed using NMR and mass spectra, and the respective data are provided as Supporting Information.

In Vitro Antifungal Activity. The hexane, ethyl acetate and methanol extracts and chemical constituents isolated from $P$. reticulata were tested for their antifungal activity against pathogenic fungi, namely, S. rolfsii, $R$. solani, $R$. bataticola, F. odum, P. aphanidermatum and $P$. debaryanum, at various concentrations by the poisoned food technique $^{15}$ using potato dextrose agar media (PDA media) against the standard fungicide hexaconazole. The ready-made PDA medium (39 g) was suspended in distilled water $(1000 \mathrm{~mL})$ and heated to boiling until completely dissolved. The medium and Petri dishes were autoclaved at $120^{\circ} \mathrm{C}$ for $30 \mathrm{~min}$. A stock solution of $1000 \mu \mathrm{g} \mathrm{mL}{ }^{-1}$ of the test compound was prepared, which was further diluted with acetone to give the required concentrations of 250,125 , and $62.5 \mu \mathrm{g} \mathrm{mL}^{-1}$. Acetone $(1 \mathrm{~mL})$ was used as the control. These solutions were added to the media $(65 \mathrm{~mL})$ contained in conical flasks to obtain the desired concentrations of the test compounds in the media. The medium was poured into a set of two Petri dishes ( $9 \mathrm{~cm}$ in diameter) under aseptic conditions in a laminar flow hood. The plates were kept under UV light in the laminar flow chamber for solidification of the media. After solidification, a $5 \mathrm{~mm}$ mycelial disk cut from the actively growing front of a 2-week-old colony of the desired pathogenic fungus was then placed with the inoculum side down in the center of each treated plate, aseptically. Treated Petri dishes were then incubated at $28^{\circ} \mathrm{C}$ until the fungal growth was almost complete in the control plates. All experiments were in quadruplicate for each treatment against each fungus.

Recording of Observations. The mycelial growth of fungus $(\mathrm{cm})$ in both treated $(\mathrm{T})$ and control (C) Petri dishes was measured diametrically. The mean and standard deviation were calculated from the four replicates of each treatment and the percentage inhibition of growth (\% I) was calculated using the following formula:

$$
I(\%)=\frac{C-T}{C} \times 100
$$

Calculation of $\mathrm{ED}_{50}$ Values. For calculation of $\mathrm{ED}_{50}$ values (effective dose required for $50 \%$ inhibition of growth), the percent inhibition was converted to corrected percent inhibition by using Abbott's formula:

$$
\text { corrected inhibition }(\%)=\frac{\% I-\mathrm{CF}}{100-\mathrm{CF}} \times 100
$$

where $\mathrm{CF}$ is the correction factor obtained by the equation

$$
\text { correction factor }(\mathrm{CF})=\frac{9-C}{C} \times 100
$$

where 9 is the diameter of the Petri dish in $\mathrm{cm}$ and $C$ is the diameter of growth of the fungus in control plates. From the concentration $(\mu \mathrm{g}$ $\mathrm{mL}^{-1}$ ) and corresponding corrected percentage inhibition data of each compound, the $\mathrm{ED}_{50}\left(\mu \mathrm{g} \mathrm{mL}^{-1}\right)$ value was calculated statistically by Probit analysis with the help of Probit package of MSTATC software using a personal computer. $\mathrm{ED}_{50}$ values were calculated (effective dose for $50 \%$ inhibition $\mu \mathrm{g} \mathrm{mL}^{-1}$ ) for inhibition of growth using the Basic $\mathrm{LD}_{50}$ program version 1.1.

Statistical Treatment of the Data. The experimental data were statistically analyzed and analysis of variance was computed using Statistical Package for Social Services (SPSS version 10.0), and treatment means were compared by using Duncan's multiple range test (DMRT) at 5\% levels.

\section{RESULTS AND DISCUSSION}

Samples of $P$. reticulata collected from Kilberi forest ranges (Northern Himalayas), Uttarakhand, India, were dried at room temperature and extracted with hexane, ethyl acetate and methanol. The extracts after removal of solvents were screened for antifungal activity, and major chemical constituents were isolated by column chromatography. 


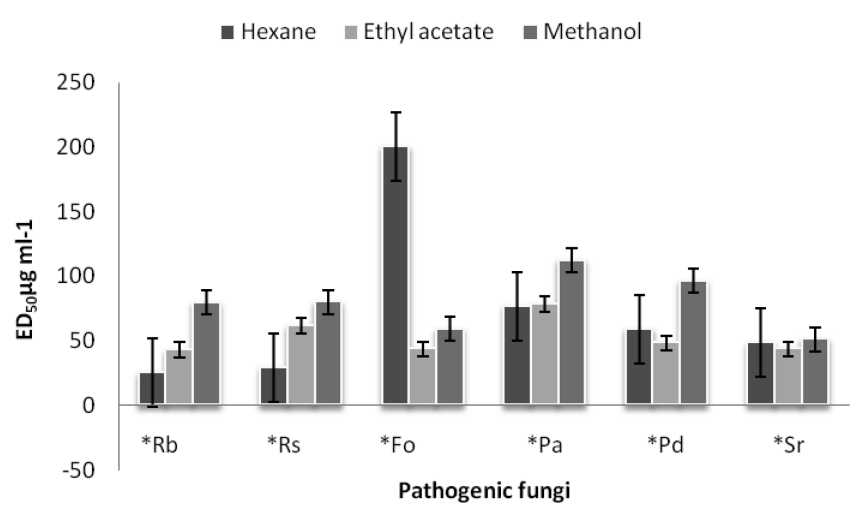

Figure 1. Antifungal activity of hexane, ethyl acetate and methanol extracts of $P$. reticulata. ${ }^{*} \mathrm{Rb}=$ Rhizoctonia bataticola; ${ }^{*} \mathrm{Rs}=$ Rhizoctonia solani $;{ }^{*} \mathrm{Fo}=$ Fusarium udum; ${ }^{*} \mathrm{~Pa}=$ Pythium aphanidermatum; ${ }^{*} \mathrm{Pd}=$ Pythium debaryanum; ${ }^{*} \mathrm{Sr}=$ Sclerotium rolfsii.

Antifungal Activity of Solvent Extracts. The antifungal activity of hexane, ethyl acetate and methanol extracts of $P$. reticulata against $S$. rolssii, $R$. solani, $R$. bataticola, F. udum, $P$. aphanidermatum and $P$. debaryanum using the poisoned food technique was estimated on the basis of the presence and absence of inhibition, their diameter and values of $\mathrm{ED}_{50}$. The results are presented in Figure 1.

The antifungal activity of these extracts was found to be selective. The largest zones of inhibition were recorded with hexane extract against $R$. bataticola $\left(\mathrm{ED}_{50}=25.1 \mu \mathrm{g} \mathrm{mL}^{-1}\right)$ followed by $R$ solani $\left(\mathrm{ED}_{50}=29.4 \mu \mathrm{g} \mathrm{mL}^{-1}\right)$, S. rolfsii $\left(\mathrm{ED}_{50}=\right.$ $\left.48.4 \mu \mathrm{g} \mathrm{mL}^{-1}\right)$, P. debaryanum $\left(\mathrm{ED}_{50}=59.2, \mu \mathrm{g} \mathrm{mL}^{-1}\right)$ and P. aphanidermatum $\left(\mathrm{ED}_{50}=76.8 \mu \mathrm{g} \mathrm{mL}^{-1}\right)$ (Figure 1). The hexane extract showed minimum zone of inhibition against $F$. udum $\left(\mathrm{ED}_{50}=200.3 \mu \mathrm{g} \mathrm{mL}^{-1}\right)$ as compared to other test pathogens (Figure 1), whereas the ethyl acetate extract showed maximum inhibition against F. $u d u m\left(\mathrm{ED}_{50}=43.7 \mu \mathrm{g} \mathrm{mL}^{-1}\right)$ and S. rolfsii $\left(\mathrm{ED}_{50}=43.7 \mu \mathrm{g} \mathrm{mL}^{-1}\right)$, followed by P. debaryanum $\left(\mathrm{ED}_{50}=48.4\right.$ $\left.\mu \mathrm{g} \mathrm{mL}^{-1}\right)$ and $P$. aphanidermatum $\left(\mathrm{ED}_{50}=78.4 \mu \mathrm{g} \mathrm{mL}^{-1}\right)$ (Figure 1). Methanol extract showed maximum inhibition against $S$. rolfsii $\left(\mathrm{ED}_{50}=51.2 \mu \mathrm{g} \mathrm{mL}^{-1}\right)$ followed by $F$. udum $\left(\mathrm{ED}_{50}=59.2, \mu \mathrm{g} \mathrm{mL}^{-1}\right)$, R. bataticola $\left(\mathrm{ED}_{50}=79.5 \mu \mathrm{g} \mathrm{mL}^{-1}\right)$, $R$. solani $\left(\mathrm{ED}_{50}=80.1 \mu \mathrm{g} \mathrm{mL}^{-1}\right)$, P. debaryanum $\left(\mathrm{ED}_{50}=96.4, \mu \mathrm{g}\right.$ $\left.\mathrm{mL}^{-1}\right)$ and P. aphanidermatum $\left(\mathrm{ED}_{50}=80.1 \mu \mathrm{g} \mathrm{mL}^{-1}\right)$. All the three extracts were found to be equally active against $S$. rolfsii (Figure 1). Maximum antifungal activity was exhibited by hexane extract against $R$. bataticola $\left(\mathrm{ED}_{50}=25.1 \mu \mathrm{g} \mathrm{mL} L^{-1}\right)$. The methanol extract was slightly less active in comparison to hexane and ethyl acetate extracts. The present bioassay with the crude extracts of $P$. reticulata against soilborne pathogenic fungi is comparable to the crude extracts of $P$. sulcata, where the MIC ranged from $0.78 \mathrm{mg} / \mathrm{mL}$ against Candida albicans, Mucor mucedo, and Saccharomyces cerevisiae to $50 \mathrm{mg} / \mathrm{mL}$ against Aspergillus flavus. ${ }^{16}$ Thus these results confirm the previously observed activities of lichen extracts. The finding revealed that antifungal activity of these extracts may be due to the presence of antifungal compounds. Therefore these extracts were subjected to column chromatography for isolation and identification of antifungal compounds.

Isolation of Chemical Constituents from $P$. reticulata. Chemical constituents isolated and identified from hexane, ethyl acetate and methanol extracts by column chromatography are described below.

Hexane Extract. The following three major compounds (I-III) were isolated, purified either by preparative TLC or recrystallization and characterized based on ${ }^{1} \mathrm{H} N M R,{ }^{13} \mathrm{C}$ NMR and high resolution mass spectrometry from the hexane extract of $P$. reticulata.

Compound I. The ${ }^{1} \mathrm{H}$ NMR revealed three downfield singlets at $\delta 11.0,13.29$ and 18.91, which correspond to three intramolecular hydrogen bonds, two singlets each of three protons at $\delta 2.68$ and $\delta 2.65$ for aromatic acetyl group, and two singlets each of three protons at $\delta 2.09$ and 1.75 for aromatic methyl groups. It also showed a one proton singlet at $\delta 5.96$ for aromatic proton. ${ }^{13} \mathrm{C}$ NMR revealed the presence of carbonyl carbons at $\delta 201.6$, 200.1 and $\delta$ 197.9. The (-)-ESI mass spectrum showed a molecular ion peak at $m / z 343.0[\mathrm{M}-\mathrm{H}]^{-}$. HR-ESIMS: $m / z 367.0788$ $[\mathrm{M}+\mathrm{Na}]^{+}$calculated for $\mathrm{C}_{18} \mathrm{H}_{16} \mathrm{O}_{7} \mathrm{Na}$. The ${ }^{1} \mathrm{H}$ NMR and mass spectral data for compound I were identical to those of isousnic acid, ${ }^{17}$ thus it was identified as 2,9-diacetyl-8,10-dihydroxy-7,12b-dimethyl-1,3- $(2 \mathrm{H}, 12 \mathrm{bH})$-dibenzofurandione (isousnic acid) (Figure 2, I).

Compound II. The ${ }^{1} \mathrm{H}$ NMR spectrum displayed one singlet at $\delta 3.96$ for $\mathrm{OCH}_{3}$ and three singlets at $\delta 2.67,2.52$, and 2.07 for three aromatic $\mathrm{CH}_{3}$. It also showed an aldehyde proton at $\delta$ 10.33 and three hydroxyl protons at $\delta 12.53,12.48$, and 11.93 . Singlets at $\delta 6.49$ and $\delta 6.38$ confirmed the presence of two aromatic protons. The ${ }^{13} \mathrm{C}$ NMR spectrum revealed ester carbonyl groups at $\delta 172.0$ and 169.5 and an aldehyde carbonyl group at $\delta$ 193.6. The mass spectrum showed molecular ion peaks at $m / z 374\left(\mathrm{M}^{+}\right)$and $771\left(\mathrm{ESI},[2 \mathrm{M}+\mathrm{Na}]^{+}\right) .(+)-\mathrm{HR}$ ESIMS afforded the value at $\mathrm{m} / z 397.0893$ corresponding to the formula $\mathrm{C}_{19} \mathrm{H}_{18} \mathrm{O}_{8} \mathrm{Na}$. Based on ${ }^{1} \mathrm{H}$ NMR, ${ }^{13} \mathrm{C}$ NMR and mass spectrum it was identified as 3-hydroxy-4-(methoxycarbonyl)2,5-dimethylphenyl 3-formyl-2,4-dihydroxy-6-methylbenzoate (atranorin) (Figure 2, II). Its structure was further confirmed by comparison of its ${ }^{1} \mathrm{H}$ NMR and ${ }^{13} \mathrm{C}$ NMR spectra with a literature report. ${ }^{18}$

Compound III. The ${ }^{1} \mathrm{H}$ NMR spectrum revealed a hydroxyl proton at $\delta 11.01$, methylene protons attached to the double bond at $\delta 6.43$ and 6.03 as doublets, a triplet at $\delta 0.89$ for $\mathrm{CH}_{3} \mathrm{CH}_{2}-$, and a multiplet for 22 protons at $\delta 1.2-1.4$ indicating the presence of a long alkyl chain. ${ }^{13} \mathrm{C}$ NMR showed the presence of an acid carbonyl at $\delta 173.8$, and the carbonyl of a $\alpha, \beta$-unsaturated lactone at $\delta 163.1$. The carbon attached to the double bond showed a downfield shift at $\delta 132.35$. HR-ESIMS spectrum showed a molecular ion peak at $m / z 323.2227[\mathrm{M}-\mathrm{H}]^{+}$ calculated for $\mathrm{C}_{19} \mathrm{H}_{31} \mathrm{O}_{4}$. Based on the spectral data, compound III was identified as tetrahydro-4-methylene-5-oxo-2-tridecyl-3-furancarboxylic acid (protolichesterinic acid) (Figure 2, III). Its structure was further confirmed by comparison of its ${ }^{1} \mathrm{H}$ NMR and ${ }^{13} \mathrm{C}$ NMR with a literature report. ${ }^{19}(+)$-Protolichesterinic acid has already been reported from Cetraria islandica and Parmelia nepalensis Tayl. ${ }^{20}$ It is the first report showing the presence of protolichesterinic acid in P. reticulata.

Ethyl Acetate Extract. The following major compounds (IV-XI) were isolated, purified by either preparative TLC or recrystallization and characterized based on ${ }^{1} \mathrm{H}$ NMR, ${ }^{13} \mathrm{C}$ NMR and high resolution mass spectrometry from ethyl acetate extract of $P$. reticulata.

Compound IV. A compound with characteristic smell (smell of oak moss) was isolated, which has been known for from a long time to be used in perfumery and the cosmetic industry. ${ }^{21}$ The ${ }^{1} \mathrm{H}$ NMR spectrum revealed the presence of an aromatic proton at $\delta 6.17$, two aromatic methyl groups at $\delta 2.36$ and 1.96 , and one methoxyl at $\delta 3.84 .{ }^{13} \mathrm{C}$ NMR spectral data showed the characteristic carbonyl carbon at $\delta$ 173.7. The mass spectrum showed 
<smiles>CC(=O)C1=C(O)C=C2Oc3c(C)c(O)c(C(C)=O)c(O)c3[C@]2(C)C1=O</smiles><smiles>C=C1C(=O)OC(CCCCCCCCCCCCC)C1C(=O)O</smiles>

III<smiles>CCOC(=O)c1c(C)cc(O)c(C=O)c1O</smiles>

V<smiles>COc1cc(C)c(C(=O)O)c(O)c1C</smiles>

VIII<smiles>COc1cc(C)c(C(=O)Oc2cc(C)c(C(=O)O)c(O)c2C)c(O)c1C=O</smiles><smiles>COC(=O)c1c(C)cc(OC(=O)c2c(C)cc(O)c(C=O)c2O)c(C)c1O</smiles><smiles>COC(=O)c1c(C)cc(O)c(C)c1O</smiles>

IV<smiles>COC(=O)c1c(C)cc(O)c(C=O)c1O</smiles>

VII<smiles>COc1cc(C)c2c(=O)c3c(O)cc(OC)cc3oc2c1</smiles>

IX<smiles>Cc1cc(O)c(C=O)c2c1C(=O)Oc1c(CO)c(O)c3c(c1O2)C(O)OC3=O</smiles>

$\mathrm{XI}$

Figure 2. Structures of the chemical constituents isolated from $P$. reticulata.

a molecular ion peak at $m / z 196$, with fragment ion peaks at $\mathrm{m} / z$ 164 (88), 136 (100), 107 (16). Its ${ }^{1} \mathrm{H}$ NMR and ${ }^{13} \mathrm{C}$ NMR data were comparable to those reported earlier. ${ }^{21}$ Based on spectral data compound IV was identified as methyl 2,4-dihydroxy-3,6dimethylbenzoate (evernyl) (Figure 2, IV).

Compound V. ${ }^{1} \mathrm{H}$ NMR revealed the presence of two hydroxyl protons at $\delta 12.96$ and 12.38 , a characteristic aldehyde proton at $\delta 10.31$, an aromatic proton at $\delta 6.26$, and a quartet at $\delta 4.40$ due to the splitting of $\mathrm{CH}_{2}$ protons because of adjacent methyl protons. The ${ }^{13} \mathrm{C}$ NMR revealed an aldehyde carbon at $\delta$ 193.7. The mass spectrum showed a molecular ion peak at $\mathrm{m} / z 204$ $\left[\mathrm{M}^{+}\right]$with fragment ion peak peaks at $m / z 195$ (24), 177 (26) and 149 (100), 121 (10). From the high resolution mass spectrum its molecular formula was calculated as $\mathrm{C}_{11} \mathrm{H}_{13} \mathrm{O}_{5}[\mathrm{M}+\mathrm{H}]^{+}$ for mass 225.0757. Based on ${ }^{1} \mathrm{H}$ NMR and ${ }^{13} \mathrm{C}$ NMR and mass spectra it was identified as ethyl 3-formyl-2,4-dihydroxy-6methylbenzoate (ethyl hematommate) (Figure 2, V).

Compound VI. The ${ }^{1} \mathrm{H}$ NMR revealed the presence of $\mathrm{CH}_{3} \mathrm{CH}_{2} \mathrm{O}$ protons, aromatic hydroxyl and methyl protons. ${ }^{13} \mathrm{C}$ NMR showed a carbonyl of ester at $\delta 171.5$ and a carbon attached to the hydroxyl at $\delta 165.2$ and 159.9. The mass spectrum showed a molecular ion peak at $m / z 196\left(\mathrm{M}^{+}\right)$, with fragment ion peaks at $m / z 164(15 \%)\left(\mathrm{M}^{+}-\mathrm{CH}_{3}\right)$ and $m / z 150$
(100\%) $\left(\mathrm{M}^{+}-\mathrm{CH}_{2} \mathrm{CH}_{3}\right)$. HMBC spectral data showed that an ethyl ester of benzoic acid is present adjacent to carbon bearing the hydroxyl group. Based on ${ }^{1} \mathrm{H}$ NMR and ${ }^{13} \mathrm{C}$ NMR it was characterized as ethyl 2,4-dihydroxy-6-methylbenzoate (ethyl orsellinate) (Figure 2, VI).

Compound VII. ${ }^{1} \mathrm{H}$ NMR was similar to compound V except it showed the presence of methyl ester rather than ethyl ester. The mass spectrum showed a molecular ion peak at $m / z 209$ for $[M+$ $\mathrm{H}]^{+}$. High resolution MS gave a value at 209.0455 for the molecular formula $\mathrm{C}_{10} \mathrm{H}_{10} \mathrm{O}_{5}$. Based on ${ }^{1} \mathrm{H} \mathrm{NMR}$ and ${ }^{13} \mathrm{C} \mathrm{NMR}$ and mass spectral data, it was identified as methyl 3-formyl-2,4-dihydroxy-6methylbenzoate (methyl hematommate) (Figure 2, VII).

Compound VIII. The ${ }^{1} \mathrm{H}$ NMR revealed the presence of two singlets of three protons each at $\delta 2.70$ and 2.30 for aromatic $\mathrm{CH}_{3}$, and three proton singlets at $\delta 3.90$ for $\mathrm{OCH}_{3} \cdot{ }^{13} \mathrm{C} \mathrm{NMR}$ showed the presence of carbonyl carbon of the acid group at $\delta$ 172.6. DEPT showed the presence of six quaternary, one methane and three methyl carbons. The mass spectrum showed a molecular ion peak at $m / z 196\left(\mathrm{M}^{+}\right)$. Based on the spectral data, compound VIII was identified as 2-hydroxy-4-methoxy-3,6dimethylbenzoic acid (Figure 2, VIII).

Compound IX. The ${ }^{1} \mathrm{H}$ NMR revealed the presence of one hydroxyl at $\delta 13.53$, two aromatic protons at $\delta 6.86$ and 6.28 , a 
Table 1. Antifungal Activities of Chemical Constituents Isolated from Various Solvent Extracts of P. reticulata against Pathogenic Fungi $^{a}$

\begin{tabular}{|c|c|c|c|c|}
\hline \multirow[b]{2}{*}{ test fungi ${ }^{b}$} & \multicolumn{3}{|c|}{ inhibition (\%) } & \multirow[b]{2}{*}{$\mathrm{ED}_{50}\left(\mu \mathrm{g} \mathrm{mL}^{-1}\right)$} \\
\hline & $250\left(\mu \mathrm{g} \mathrm{mL}^{-1}\right)^{c}$ & $125\left(\mu \mathrm{g} \mathrm{mL}^{-1}\right)^{c}$ & $62.5\left(\mu \mathrm{g} \mathrm{mL}^{-1}\right)^{c}$ & \\
\hline \multicolumn{5}{|c|}{ Isousnic Acid } \\
\hline $\mathrm{Sr}$ & $84.00 \pm 1.41$ & $66.10 \pm 2.78$ & $32.80 \pm 0.87$ & $69.63 \pm 0.46$ \\
\hline Rs & $86.37 \pm 1.02$ & $73.13 \pm 0.35$ & $35.20 \pm 1.10$ & $64.62 \pm 0.46$ \\
\hline $\mathrm{Rb}$ & $87.17 \pm 1.25$ & $69.10 \pm 0.88$ & $29.30 \pm 3.90$ & $70.36 \pm 0.47$ \\
\hline Fo & $81.00 \pm 1.34$ & $63.33 \pm 0.94$ & $33.40 \pm 2.77$ & $70.86 \pm 0.45$ \\
\hline $\mathrm{Pa}$ & $75.40 \pm 2.95$ & $53.16 \pm 1.73$ & $46.10 \pm 3.10$ & $62.30 \pm 1.07$ \\
\hline $\mathrm{Pd}$ & $72.10 \pm 1.60$ & $66.23 \pm 1.60$ & $35.13 \pm 0.90$ & $70.98 \pm 0.44$ \\
\hline \multicolumn{5}{|c|}{ Atranorin } \\
\hline $\mathrm{Sr}$ & $100 \pm 1.00$ & $89.67 \pm 1.08$ & $67.34 \pm 1.33$ & $39.70 \pm 1.33$ \\
\hline Rs & $81.33 \pm 1.73$ & $62.00 \pm 0.41$ & $40.00 \pm 0.85$ & $64.63 \pm 0.93$ \\
\hline $\mathrm{Rb}$ & $80.00 \pm 2.64$ & $67.67 \pm 1.22$ & $44.33 \pm 0.94$ & $58.82 \pm 0.44$ \\
\hline Fo & $90.00 \pm 1.00$ & $81.34 \pm 0.61$ & $50.00 \pm 0.17$ & $50.32 \pm 0.47$ \\
\hline $\mathrm{Pa}$ & $60.33 \pm 2.30$ & $43.00 \pm 0.81$ & $22.00 \pm 0.60$ & $104.73 \pm 0.46$ \\
\hline $\mathrm{Pd}$ & $89.67 \pm 1.50$ & $78.00 \pm 0.60$ & $56.33 \pm 0.75$ & $44.79 \pm 0.46$ \\
\hline \multicolumn{5}{|c|}{ Protolichesterinic Acid } \\
\hline $\mathrm{Sr}$ & $90.00 \pm 0.91$ & $72.16 \pm 0.23$ & $39.33 \pm 0.94$ & $61.41 \pm 0.46$ \\
\hline Rs & $83.33 \pm 0.40$ & $77.00 \pm 0.72$ & $67.00 \pm 0.20$ & $23.09 \pm 0.46$ \\
\hline $\mathrm{Rb}$ & $89.33 \pm 0.75$ & $50.00 \pm 0.10$ & $28.33 \pm 0.66$ & $77.64 \pm 2.03$ \\
\hline Fo & $90.33 \pm 1.13$ & $78.00 \pm 0.45$ & $44.33 \pm 0.80$ & $55.68 \pm 0.47$ \\
\hline $\mathrm{Pa}$ & $80.33 \pm 1.89$ & $72.33 \pm 1.20$ & $44.33 \pm 0.85$ & $57.10 \pm 0.44$ \\
\hline $\mathrm{Pd}$ & $100 \pm 1.66$ & $90.00 \pm 1.58$ & $78.32 \pm 1.04$ & $16.07 \pm 1.04$ \\
\hline \multicolumn{5}{|c|}{ Evernyl } \\
\hline $\mathrm{Sr}$ & $74.32 \pm 0.75$ & $50.00 \pm 1.49$ & $33.00 \pm 1.11$ & $80.21 \pm 1.05$ \\
\hline Rs & $80.33 \pm 1.20$ & $67.00 \pm 0.52$ & $46.00 \pm 0.62$ & $57.50 \pm 0.44$ \\
\hline $\mathrm{Rb}$ & $90.34 \pm 2.90$ & $50.33 \pm 1.04$ & $28.33 \pm 1.04$ & $77.21 \pm 2.13$ \\
\hline Fo & $80.46 \pm 0.47$ & $50.00 \pm 0.00$ & $26.67 \pm 0.50$ & $82.31 \pm 1.32$ \\
\hline $\mathrm{Pa}$ & $88.30 \pm 1.04$ & $50.00 \pm 0.20$ & $22.33 \pm 0.66$ & $81.50 \pm 1.92$ \\
\hline $\mathrm{Pd}$ & $89.33 \pm 1.03$ & $72.33 \pm 0.96$ & $44.00 \pm 0.92$ & $56.96 \pm 0.46$ \\
\hline \multicolumn{5}{|c|}{ Ethyl Hematommate } \\
\hline $\mathrm{Sr}$ & $61.00 \pm 0.62$ & $47.50 \pm 3.34$ & $28.40 \pm 0.70$ & $98.97 \pm 0.44$ \\
\hline Rs & $55.47 \pm 2.00$ & $33.53 \pm 0.70$ & $15.30 \pm 4.64$ & $124.98 \pm 0.49$ \\
\hline $\mathrm{Rb}$ & $53.36 \pm 1.68$ & $42.80 \pm 0.79$ & $27.40 \pm 2.80$ & $117.35 \pm 0.44$ \\
\hline Fo & $27.40 \pm 0.72$ & $13.46 \pm 2.77$ & $6.40 \pm 1.01$ & $250.36 \pm 0.63$ \\
\hline $\mathrm{Pa}$ & $50.40 \pm 0.43$ & $32.60 \pm 2.21$ & $13.06 \pm 2.64$ & $132.69 \pm 0.50$ \\
\hline $\mathrm{Pd}$ & $56.47 \pm 1.90$ & $26.30 \pm 0.70$ & $15.13 \pm 0.41$ & $128.50 \pm 1.43$ \\
\hline \multicolumn{5}{|c|}{ Ethyl Orsellinate } \\
\hline $\mathrm{Sr}$ & $78.00 \pm 0.43$ & $50.50 \pm 1.30$ & $28.30 \pm 0.10$ & $82.69 \pm 1.19$ \\
\hline Rs & $90.36 \pm 0.81$ & $68.06 \pm 1.58$ & $44.36 \pm 0.92$ & $58.33 \pm 1.24$ \\
\hline $\mathrm{Rb}$ & $67.16 \pm 0.85$ & $28.00 \pm 2.20$ & $16.36 \pm 0.86$ & $113.75 \pm 1.98$ \\
\hline Fo & $79.43 \pm 1.72$ & $32.46 \pm 1.13$ & $17.33 \pm 0.85$ & $98.20 \pm 2.35$ \\
\hline $\mathrm{Pa}$ & $83.30 \pm 1.83$ & $50.36 \pm 2.21$ & $18.50 \pm 2.52$ & $86.92 \pm 1.44$ \\
\hline $\mathrm{Pd}$ & $91.36 \pm 0.83$ & $61.23 \pm 1.16$ & $28.33 \pm 2.95$ & $72.51 \pm 1.51$ \\
\hline \multicolumn{5}{|c|}{ Methyl Hematommate } \\
\hline $\mathrm{Sr}$ & $89.16 \pm 1.19$ & $66.60 \pm 0.65$ & $44.208 \pm 1.24$ & $60.33 \pm 1.59$ \\
\hline Rs & $81.70 \pm 5.31$ & $72.60 \pm 3.06$ & $50.63 \pm 3.31$ & $50.52 \pm 0.44$ \\
\hline $\mathrm{Rb}$ & $78.20 \pm 3.21$ & $61.43 \pm 0.58$ & $53.13 \pm 0.95$ & $52.90 \pm 1.64$ \\
\hline Fo & $67.33 \pm 1.70$ & $50.46 \pm 0.75$ & $46.46 \pm 0.70$ & $71.22 \pm 0.43$ \\
\hline $\mathrm{Pa}$ & $69.26 \pm 0.41$ & $46.36 \pm 2.70$ & $24.43 \pm 1.80$ & $90.59 \pm 0.45$ \\
\hline
\end{tabular}


Table 1. Continued

\begin{tabular}{|c|c|c|c|c|}
\hline \multirow[b]{2}{*}{ test fungi ${ }^{b}$} & \multicolumn{3}{|c|}{ inhibition (\%) } & \multirow[b]{2}{*}{$\mathrm{ED}_{50}\left(\mu \mathrm{g} \mathrm{mL}^{-1}\right)$} \\
\hline & $250\left(\mu \mathrm{g} \mathrm{mL}^{-1}\right)^{c}$ & $125\left(\mu \mathrm{g} \mathrm{mL}^{-1}\right)^{c}$ & $62.5\left(\mu \mathrm{g} \mathrm{mL}^{-1}\right)^{c}$ & \\
\hline $\mathrm{Pd}$ & $71.33 \pm 3.31$ & $47.26 \pm 1.67$ & $34.00 \pm 1.35$ & $88.20 \pm 0.40$ \\
\hline \multicolumn{5}{|c|}{ 2-Hydroxy-4-methoxy-3,6-dimethylbenzoic Acid } \\
\hline $\mathrm{Sr}$ & $53.00 \pm 1.41$ & $44.30 \pm 4.64$ & $28.36 \pm 2.27$ & $115.56 \pm 0.44$ \\
\hline Rs & $82.00 \pm 1.30$ & $70.60 \pm 2.21$ & $50.00 \pm 0.85$ & $50.65 \pm 0.44$ \\
\hline $\mathrm{Rb}$ & $68.00 \pm 0.17$ & $56.40 \pm 2.80$ & $39.40 \pm 1.82$ & $74.48 \pm 0.43$ \\
\hline Fo & $58.00 \pm 0.10$ & $46.46 \pm 0.70$ & $23.66 \pm 0.35$ & $106.13 \pm 0.45$ \\
\hline $\mathrm{Pa}$ & $79.33 \pm 2.30$ & $67.66 \pm 0.70$ & $28.36 \pm 0.64$ & $71.11 \pm 0.90$ \\
\hline $\mathrm{Pd}$ & $83.83 \pm 0.87$ & $61.40 \pm 1.31$ & $33.00 \pm 1.70$ & $73.8 \pm 0.46$ \\
\hline \multicolumn{5}{|c|}{ Lichexanthone } \\
\hline $\mathrm{Sr}$ & $37.33 \pm 0.80$ & $23.20 \pm 3.21$ & $16.67 \pm 0.68$ & $273.33 \pm 0.48$ \\
\hline Rs & $41.00 \pm 0.72$ & $29.36 \pm 3.30$ & $19.63 \pm 1.20$ & $202.50 \pm 0.47$ \\
\hline $\mathrm{Rb}$ & $50.00 \pm 0.45$ & $30.26 \pm 0.41$ & $11.43 \pm 0.75$ & $133.76 \pm 0.52$ \\
\hline Fo & $53.33 \pm 1.04$ & $24.53 \pm 0.70$ & $20.33 \pm 0.94$ & $151.03 \pm 1.57$ \\
\hline $\mathrm{Pa}$ & $42.66 \pm 1.80$ & $23.40 \pm 2.80$ & $13.03 \pm 0.20$ & $174.14 \pm 1.02$ \\
\hline $\mathrm{Pd}$ & $42.03 \pm 1.27$ & $28.40 \pm 0.70$ & $9.03 \pm 0.95$ & $148.95 \pm 0.56$ \\
\hline \multicolumn{5}{|c|}{ Baeomycesic Acid } \\
\hline $\mathrm{Sr}$ & $72.40 \pm 0.62$ & $44.43 \pm 1.73$ & $32.20 \pm 0.36$ & $86.65 \pm 1.28$ \\
\hline Rs & $81.63 \pm 0.75$ & $61.40 \pm 2.36$ & $33.40 \pm 0.91$ & $71.28 \pm 0.45$ \\
\hline $\mathrm{Rb}$ & $49.13 \pm 3.44$ & $28.40 \pm 2.77$ & $17.10 \pm 0.36$ & $149.87 \pm 0.96$ \\
\hline Fo & $57.86 \pm 0.20$ & $47.13 \pm 0.94$ & $33.46 \pm 0.94$ & $109.85 \pm 0.33$ \\
\hline $\mathrm{Pa}$ & $44.40 \pm 2.00$ & $29.30 \pm 0.45$ & $11.36 \pm 2.66$ & $148.90 \pm 0.52$ \\
\hline $\mathrm{Pd}$ & $77.14 \pm 1.25$ & $38.23 \pm 2.90$ & $18.30 \pm 1.04$ & $143.50 \pm 0.46$ \\
\hline \multicolumn{5}{|c|}{ Salazinic Acid } \\
\hline $\mathrm{Sr}$ & $38.20 \pm 0.36$ & $21.03 \pm 1.26$ & $5.93 \pm 0.15$ & $164.10 \pm 0.62$ \\
\hline Rs & $45.20 \pm 1.10$ & $30.20 \pm 2.00$ & $22.10 \pm 1.17$ & $179.47 \pm 0.46$ \\
\hline $\mathrm{Rb}$ & $41.20 \pm 1.24$ & $26.80 \pm 0.60$ & $9.00 \pm 1.91$ & $161.35 \pm 0.55$ \\
\hline Fo & $67.00 \pm 1.34$ & $50.13 \pm 2.66$ & $31.00 \pm 0.36$ & $88.20 \pm 0.44$ \\
\hline $\mathrm{Pa}$ & $61.00 \pm 1.35$ & $25.50 \pm 0.87$ & $11.06 \pm 0.61$ & $121.22 \pm 1.74$ \\
\hline $\mathrm{Pd}$ & $43.46 \pm 1.13$ & $28.06 \pm 0.15$ & $11.93 \pm 1.87$ & $150.67 \pm 0.51$ \\
\hline \multicolumn{5}{|c|}{ inhibition (\%) } \\
\hline test fungi ${ }^{b}$ & $31.00\left(\mu \mathrm{g} \mathrm{mL}^{-1}\right)^{c}$ & $15.50\left(\mu \mathrm{g} \mathrm{mL}^{-1}\right)^{c}$ & $7.25\left(\mu \mathrm{g} \mathrm{mL}^{-1}\right)^{c}$ & $\mathrm{ED}_{50}\left(\mu \mathrm{g} \mathrm{mL}^{-1}\right)$ \\
\hline \multicolumn{5}{|c|}{ Hexaconazole } \\
\hline $\mathrm{Sr}$ & $90.66 \pm 0.47$ & $45.30 \pm 0.50$ & $28.22 \pm 0.28$ & $13.43 \pm 0.23$ \\
\hline Rs & $72.56 \pm 0.30$ & $38.20 \pm 0.70$ & $20.60 \pm 0.20$ & $18.30 \pm 0.38$ \\
\hline $\mathrm{Rb}$ & $86.96 \pm 0.36$ & $73.23 \pm 0.41$ & $60.13 \pm 0.30$ & $4.40 \pm 0.36$ \\
\hline Fo & $70.00 \pm 0.79$ & $23.66 \pm 0.26$ & $18.56 \pm 0.11$ & $22.01 \pm 0.01$ \\
\hline $\mathrm{Pa}$ & $65.26 \pm 0.56$ & $32.73 \pm 0.15$ & $14.06 \pm 0.38$ & $22.06 \pm 0.40$ \\
\hline $\mathrm{Pd}$ & $59.23 \pm 0.30$ & $26.30 \pm 0.43$ & $11.13 \pm 0.49$ & $25.92 \pm 0.41$ \\
\hline
\end{tabular}

${ }^{a}$ Mean percentage inhibition, used for $\mathrm{ED}_{50}$ calculation, is an average of four replicates and its standard error ranged from \pm 0.2 to 3.4 ; $\mathrm{ED}_{50}$ values $(\mu \mathrm{g}$ $\mathrm{mL}^{-1}$ ) calculated from mean. Percentage inhibition, which is an average of four replicates and its standard deviation ranging from 0.12 to 6.86 . Chi square for heterogeneity (tabular value at 0.05 level $)=5.99($ degrees of freedom $=3)$. The data showed not much significant difference from control at $5 \%$ level $(P>0.5) .{ }^{b} \mathrm{Sr}=$ Sclerotium rolfsii $; \mathrm{Rs}=$ Rhizoctonia solani $; \mathrm{Rb}=$ Rhizoctonia bataticola $; \mathrm{Fo}=$ Fusarium udum; Pa $=$ Pythium aphanidermatum; $\mathrm{Pd}=$ Pythium debaryanum. ${ }^{c}$ Concentration.

singlet of six protons at $\delta 3.90$ for two $\mathrm{OCH}_{3}$ and a $3 \mathrm{H}$ singlet at $\delta 2.95$ for aromatic $\mathrm{CH}_{3}$. The mass spectrum showed a molecular ion peak at $m / z 286\left(\mathrm{M}^{+}\right)$. Compound IX was identified as 1-hydroxy-3,6-dimethoxy-8-methyl-xanthen-9one (lichexanthone) (Figure 2, IX), which has been reported from P. formanosa, Pertusaria sulphurata and Anthocleista djalonensis. ${ }^{22}$
Compound X. Insoluble in most organic solvents, this substance was soluble in DMSO. The ${ }^{1} \mathrm{H}$ NMR spectrum showed the presence of two hydroxyls at $\delta 11.55$ and 10.58 , an aldehyde proton at $\delta 10.21$, two aromatic protons at $\delta 6.45$ and 6.38 , one methoxyl proton at $\delta 3.88$ and three aromatic methyls at $\delta 2.35,2.04,1.94 .{ }^{13} \mathrm{C}$ NMR revealed the presence of an aldehyde carbon at $\delta$ 193.4, carbonyl carbon of the carboxylic acid at 


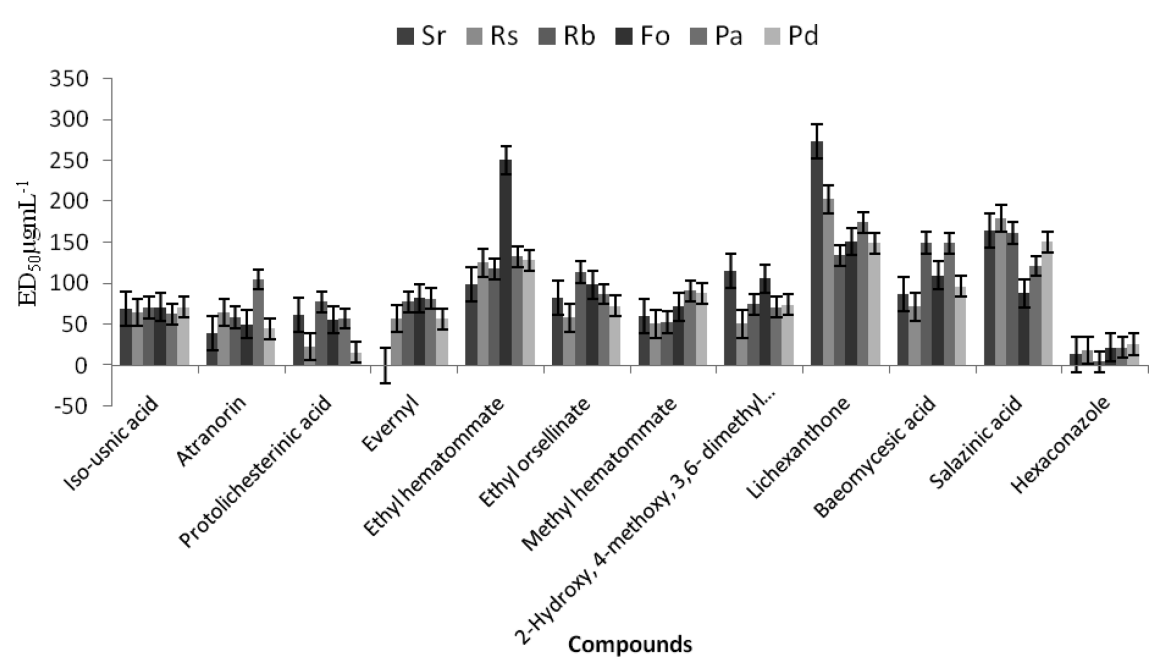

Figure 3. Antifungal activity of chemical constituents isolated from P. reticulata $\mathrm{Rb}=$ Rhizoctonia bataticola; Rs $=$ Rhizoctonia solani; Fo = Fusarium udum; $\mathrm{Pa}=$ Pythium aphanidermatum; $\mathrm{Pd}=$ Pythium debaryanum; $\mathrm{Sr}=$ Sclerotium rolfsii.

$\delta 171.5$ and the carbonyl carbon of ester at $\delta 169.5$. The mass spectrum showed a molecular ion peak at $m / z 374\left(\mathrm{M}^{+}\right) .(+)$HRESIMS $m / z 397.0895[\mathrm{M}+\mathrm{Na}]^{+}$. By comparison of its spectral data with earlier reported data, ${ }^{23}$ it was identified as baeomycesic acid (Figure 2, X).

Compound XI. The ethyl acetate extract of $P$. reticulata on cooling gave a colorless amorphous powder, which was found insoluble in most organic solvents. It was purified by repeated crystallization from acetone:water (80:20). Its ${ }^{1} \mathrm{H}$ NMR spectrum showed the presence of phenolic $\mathrm{OH}$, an aldehydic proton, aromatic methyl and a benzylic proton. ${ }^{1} \mathrm{H}$ NMR spectral data were comparable to those of salazinic acid reported earlier. ${ }^{24}$ By these data and the molecular ion peak at $m / z 387[\mathrm{M}-\mathrm{H}]^{-}$in the (-)-ESI mass spectrum, it was identified1,4,10-trihydroxy-5hydroxymethyl-8-methyl-3,7-dioxo-1,3-dihydro-7H-benzo[e]furo$[3,4]$ benzo $[1,4]$ dioxepine-11-carbaldehyde (salazinic acid), which has been isolated before from P. saxatilis ${ }^{25}$ (Figure 2, XI).

Antifungal Activity of Chemical Constituents. The antifungal activity of secondary metabolites/compounds isolated from the hexane, ethyl acetate and methanol extracts of $P$. reticulata screened against pathogenic fungi, namely, S. rolfsii, $R$. solani, R. bataticola, F. udum, P. aphanidermatum and P. debaryanum at various concentrations and their calculated $\mathrm{ED}_{50}$ values are reported in Table 1 and Figure 3. Isousnic acid (Figure 2, I) identified from the hexane extract for the first time, exhibited 72 to $87 \%$ inhibition against all the test fungi at $250 \mu \mathrm{g} \mathrm{mL}{ }^{-1}$ concentration (Table 1) with $\mathrm{ED}_{50}$ values ranging from 62.30 to $70.98 \mu \mathrm{g} \mathrm{mL}^{-1}$ (Table 1, Figure 3). Usnic acid has already been found to show remarkable antibiotic, plant growth inhibitory and enzyme inhibitory activities and also strong antibacterial activity against Gram positive organisms in vitro and antifungal effects. $^{26,27}$ Both the $(+)$ and $(-)$ enantiomers of usnic acid are effective against a large variety of Gram-positive $(\mathrm{G}+)$ bacterial strains, including strains from clinical isolates, irrespective of their resistant phenotype. Of particular relevance is the inhibition of growth of multiresistant strains of Streptococcus aureus, enterococci and mycobacteria.

Atranorin (Figure 2, II), isolated and identified from both hexane and methanol extract, exhibited 100, 89 and 67\% inhibition against $S$. rolfsii at 250,125 , and $62.5 \mu \mathrm{g} \mathrm{mL}^{-1}$ concentrations respectively with an $\mathrm{ED}_{50}$ value of $39.70 \mu \mathrm{g} \mathrm{mL}$.

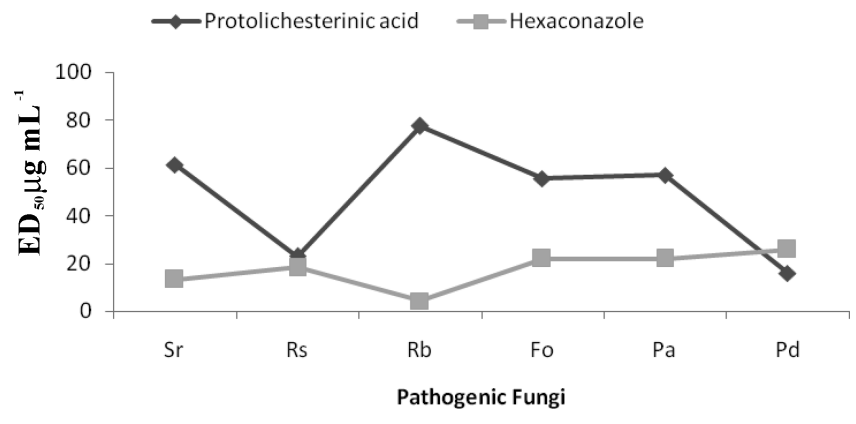

Figure 4. Comparison of antifungal activity of protolichesterinic acid with commercial fungicide hexaconazole. $\mathrm{Rb}=$ Rhizoctonia bataticola; $\mathrm{Rs}=$ Rhizoctonia solani $; \mathrm{Fo}=$ Fusarium udum $; \mathrm{Pa}=$ Pythium aphanider matum $; \mathrm{Pd}=$ Pythium debaryanum; $\mathrm{Sr}=$ Sclerotium rolfsii.

Compound II was also able to inhibit 89,78 and $56 \%$ growth of $P$. debaryanum at 250,125 , and $62.5 \mu \mathrm{g} \mathrm{mL}^{-1}$ concentration respectively $\left(\mathrm{ED}_{50}=44.79 \mu \mathrm{g} \mathrm{mL}^{-1}\right)$ (Table 1, Figure3). These results are similar to earlier reports, ${ }^{18,21}$ showing antifungal activity of atranorin against Colletotrichum gloeosporioides.

The antifungal activity of protolichesterinic acid (Figure 2, III) isolated from hexane extract was found to be more active than a commercial fungicide, hexaconazole, against $P$. debaryanum. It showed 100, 90 and $78 \%$ inhibition at 250,125 , and $62.5 \mu \mathrm{g} \mathrm{mL}^{-1}$ concentration with $\mathrm{ED}_{50}$ value of $16.07 \mu \mathrm{g} \mathrm{mL}^{-1}$ ), whereas hexaconazole showed 59.23, 26.30 and $11.30 \%$ inhibition at $31.00,15.50$, and $7.25 \mu \mathrm{g} \mathrm{mL}^{-}$concentrations with $\mathrm{ED}_{50}$ value of $25.92 \mu \mathrm{g} \mathrm{mL}^{-1}$ (Table 1 and Figure 4). Protolichesterinic acid also showed 83,77 and $67 \%$ inhibition against $R$. solani at 250,125 , and $62.5 \mu \mathrm{g} \mathrm{mL}^{-1}$ concentrations respectively $\left(\mathrm{ED}_{50}=\right.$ $23.09 \mu \mathrm{g} \mathrm{mL}^{-1)}$ (Figures 3 and 4, Table 1). The protolichesterinic acid, isolated from Iceland moss, has already been found to possess antibacterial properties against Mycobacterium tuberculosis, Streptococcus pyogenes, and Staphylococcus aureus. ${ }^{28}$ It has been further shown to exhibit antitumor activity against solid-type Ehrlich carcinoma in mice, ${ }^{29}$ potent in vitro inhibiting activity against the DNA polymerase activity of human immunodeficiency virus type 1 reverse transcriptase, and inhibitory effects on arachidonate 5-lipoxygenase from porcine leukocytes. 


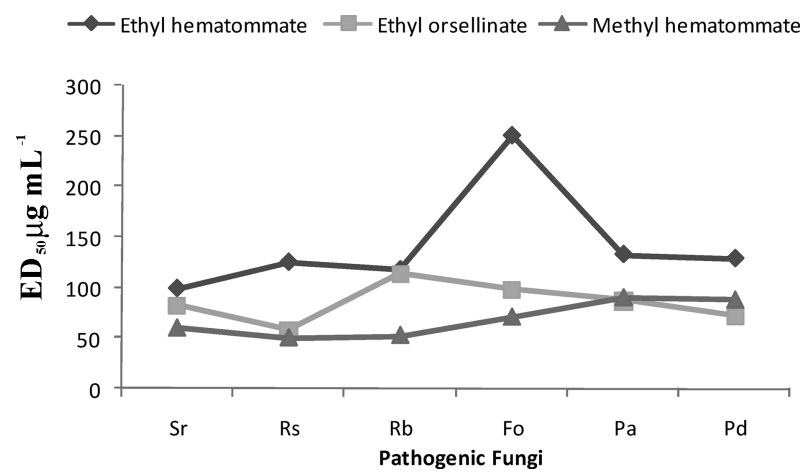

Figure 5. Comparison of antifungal activity of methyl hematommate, ethyl hematommate and ethyl orsellinate. $\mathrm{Rb}=$ Rhizoctonia bataticola; $\mathrm{Rs}=$ Rhizoctonia solani $; \mathrm{Fo}=$ Fusarium udum $; \mathrm{Pa}=$ Pythium aphanider matum; $\mathrm{Pd}=$ Pythium debaryanum; $\mathrm{Sr}=$ Sclerotium rolfsii

Evernyl (IV) was found to be moderately active against $R$ solani and $P$. debaryanum with calculated $\mathrm{ED}_{50}=57.50$ and $56.96 \mu \mathrm{g} \mathrm{mL}^{-1}$ respectively (Table 1 and Figure 3 ). The antifungal activity of isousnic acid and evernyl was at par against all the test pathogens (Figure 3). It has been reported earlier that evernic acid severely inhibited growth of Phytophthora infestans, whereas $P$. ultimum growth was slightly but significantly inhibited by evernic acid and (-)-usnic acid, respectively. ${ }^{27}$

Ethyl hematommate (V) was found to be less active as compared to methyl hematommate (VII) (Table 1, Figure 5). The methyl hematommate showed 89 to $67 \%$ inhibitions against all the test fungi as compared to ethyl hematommate, which showed 61 to $27 \%$ inhibitions at $250 \mu \mathrm{g} \mathrm{mL}^{-1}$ concentration. Thus by changing the methyl group to an ethyl group (an increase in carbon chain), there is a decrease in antifungal activity. Methyl hematommate (VII) showed moderate antifungal activity against all the test fungi with $\mathrm{ED}_{50}$ ranging from 50.52 to $90.59 \mu \mathrm{g} \mathrm{mL}^{-1}$ (Figure 5).

Ethyl orsellinate (VI) and 2-hydroxy-4-methoxy-3,6-dimethylbenzoic acid (VIII) showed maximum antifungal activity against $R$. solani with $\mathrm{ED}_{50}$ values of 58.33 and $50.65 \mu \mathrm{g} \mathrm{mL}^{-1}$ respectively. Among all the chemical constituents tested for antifungal activity, lichexanthone (IX) showed minimum inhibition against all the test fungi $\left(\mathrm{ED}_{50} 133-273 \mu \mathrm{g} \mathrm{mL}^{-1}\right)$.

Baeomycesic acid (X) was found to be moderately active against $S$. rolfsii and $R$. solani with $\mathrm{ED}_{50}$ values 86.65 and $71.28 \mu \mathrm{g} \mathrm{mL}^{-1}$ respectively as compared to other test fungi. Salazinic acid (XI) was found moderate active against F. udum with calculated $\mathrm{ED}_{50}$ value of $88.20 \mu \mathrm{g} \mathrm{mL}^{-1}$. It was found less active against other test fungi.

From the above study, it has been observed that protolichesterinic acid (III), an aliphatic $\alpha$-methylene- $\gamma$-lactone, showed maximum antifungal activity against all the test fungi as compared to other chemical constituents isolated from P. reticulata. Its activity is comparable to hexaconazole, a commercial fungicide (Table 1, Figure 4) against $P$. debaryanum and R. solani (Figure 4).

In conclusion, the antifungal activity of different solvent extracts of $P$. reticulata against different pathogenic fungi was found to be selective. The hexane extract of $P$. reticulata was found to exhibit maximum antifungal activity against $R$. solani and $R$. bataticola, whereas ethyl acetate extract showed maximum activity against $S$. rolfsii, $P$. debaryanum and F. udum. Among secondary metabolites $( \pm)$-protolichesterinic acid exhibited maximum antifungal activity against $P$. debaryanum and $R$. solani. Atranorin showed maximum activity against $S$. rolfsii and $P$. debaryanum. Among all the metabolites tested, minimum antifungal activity was exhibited by ethyl hematommate, salazinic acid and lichexanthone. Better antifungal activity of hexane extract than ethyl acetate and methanol extracts may by due to the presence of the $(+)$-protolichesterinic acid. Differences in the activity of these compounds against various fungi indicate that the compounds act in a species-specific fashion. Therefore, secondary lichen metabolites might be of potential use as antifungal agents. In conclusion, the results show that lichen extracts and lichenic acids exhibit strong effects against certain fungi, even in relatively low concentrations.

\section{ASSOCIATED CONTENT}

S Supporting Information. NMR and mass spectral data for compounds I to XI. This material is available free of charge via the Internet at http://pubs.acs.org.

\section{AUTHOR INFORMATION}

\section{Corresponding Author}

*E-mail:pd_dureja@yahoo.com.

\section{Funding Sources}

Authors are thankful to Indian Council of Agricultural Research, India, for providing funds under Emeritus Scientist Scheme.

\section{ACKNOWLEDGMENT}

Authors are thankful to Director, Indian Agricultural Research Institute, India, for providing the facilities for carrying out the work.

\section{REFERENCES}

(1) Richard, N. S.; Peter, R, S. Plant disease: A Threat to Global Food Security. Annu. Rev. Phytopathol. 2005, 43, 83-116.

(2) Agrios, G. N. Significance of plant diseases. In Plant Pathology; Academic Press: London, 2000; pp 25-37.

(3) Chattapadhyay, T. K.; Dureja, P. Antifungal activity of 4-methyl6-alkyl-2H-pyran-2-ones. J. Agric. Food Chem. 2006, 54, 2129-2133.

(4) Ellis, S. D.; Boehm, M. J.; Mitchell, T. K. Fungal and Fungal-like Diseases of Plants. In Fact sheet. Agriculture and Natural Resources; The Ohio State University Extension: Columbus, OH, 2008; pp 401-407.

(5) Donnell, K.; Kistler, C.; Cigelnik, E.; Ploetz, R. C. Multiple evolutionary origins of the fungus causing Panama disease of banana: Concordant evidence from nuclear and mitochondrial gene genealogies. Proc. Natl. Acad. Sci. U.S.A. 1998, 95, 2044-2049.

(6) Makelo, M. N.; Narla, R. D.; Mibey, R. K.; Makini, F. W. Effect of plant extracts on growth of Alternaria porri (Ellis) Cif. and other fungal pathogens of onion. J. Trop. Microbiol. Biotechnol. 2007, 3, 7-11.

(7) McLaren, J. S. Biologically active substances from higher plants: status and future potential. Pestic. Sci. 1986, 17, 559-578.

(8) Richardson, D. H. S. Lichens Man: Front. Mycol. 1991, 187-210.

(9) Lawrey, J. D. Biological role of lichen substances. Bryologist 1986, $89,111-122$.

(10) Huneck, S. The significance of lichens and their metabolites. Naturwissenschaften 1999, 86, 559-570.

(11) Dayan, F. E.; Romagni, J. G. Lichens as a potential source of pesticides. Pestic. Outlook 2001, 12, 229-232.

(12) Huneck, S.;Yoshimura, I. Identification of Lichen Substances; Springer: Berlin, 1996; pp 6-10. 
(13) Manojlovic, N. T.; Solujic, S.; Sukdolak, S.; Milosev, M. Antifungal activity of Rubia tinctorum, Rhamnus frangula and Caloplaca cerina. Fitoterapia 2005, 76(2), 244-246.

(14) Schmeda-Hirschmann, G.; Tapia, A.; Lima, B.; Pertino, M.; Sortino, M.; Zacchino, S.; Rojas de Arias, A.; Feresin, G. F. A new antifungal and antiprotozoal depside from the andean lichen Protousnea poeppigii. Phytother. Res. 2007, 22 (3), 349-355.

(15) Rollas, S.; Kalyoncuoglu, N.; Sur-Altiner, D.; Yegenglu, Y. 5-(4Aminophenyl)-4-substituted 2,4-dihydro-3H-1,2,4-triazole-3-thiones: Synthesis, antibacterial and antifungal activities. Pharmazie 1993, 48, 308.

(16) Rankovi, B.; Misic, M.; Sukdolak, S. Evaluation of Antimicrobial Activity of the Lichens Lasallia pustulata, Parmelia sulcata, Umbilicaria crustulosa and Umbilicaria cylindrical. Microbiology 2007, 76 (6), 723-727.

(17) Kutney, J. P.; Sanchez, I. H.; Yee, T. Studies in the usnic acid series- III. The base catalyzed usnic acid-isousnic acid rearrangement. The synthesis of (+)-isousnic acid. Can. J. Chem. 1976, 54 (23), 3721-3731.

(18) König, G. M.; Wright, A. D. ${ }^{1} \mathrm{H}$ and ${ }^{13} \mathrm{C}-\mathrm{NMR}$ and Biological Activity Investigations of Four Lichen-derived Compounds. Phytochem. Anal. 1999, 10, 279-284.

(19) Ingólfsdóttir, K.; Chung, G. A. C.; Skúlason, V. G.; Gissurarson, S. R.; Vilhelmdóttir, M. Antimycobacterial activity of lichen metabolites in vitro. Eur. J. Pharm. Sci. 1998, 6, 141-144.

(20) Türk, A. O.; Yilmaz, M.; Kivanç, M.; Türk, H. The Antimicrobial Activity of Extracts of the Lichen Cetraria aculeata and Its Protolichesterinic Acid Constituent. Z. Naturforsch. 2003, 58c, 850-854.

(21) Huneck, S. The Significance of Lichens and Their Metabolites. Naturwissenschaften 1999, 86, 559-570.

(22) Sundholm, E. G. ${ }^{13} \mathrm{C}$ NMR spectra of lichen xanthones. Temperature dependant collapse of long range coupling to hydrogen bonded hydroxyl protons. Acta Chem. Scand. 1978, 32, 177-181.

(23) Manojlović, N. T.; Vasiljević, P.; Jusković, M.; Najman, S.; Janković, S.; Milenković-Andjelković, A. HPLC analysis and cytotoxic potential of extracts from the lichen, Thamnolia vermicularis var. subuliformis. J. Med. Plants Res. 2010, 4 (9), 817-823.

(24) Huneck, S.; Linscheid, P. NMR spektoskopic einiger Depside and Depsidone. Z. Naturforsch. 1968, 23B (5), 717-732.

(25) Nolan, T. J.; Keane, J. Salazinic Acid and the Constituents of the Lichen, Lobaria pulmonaria. Nature 1933, 132, 281.

(26) Cocchietto, M.; Skert, N.; Nimis, P. L.; Sava, G. A review on usnic acid, an interesting natural compound. Naturwissenchaften 2002, 89, 137-146.

(27) Lauterwein, M.; Oethinger, M.; Belsner, K.; Peters, T.; Marre, $\mathrm{R}$. In vitro activities of the lichen secondary metabolites vulpinic acid, $(+)$-usnic acid and (-)-usnic acid against aerobic and anaerobic microorganisms. Antimicrob. Agents Chemother. 1995, 39, 2541-2543.

(28) Stoll, A.; Brack, A.; Renz, J. Die Wirkung von Flechtenstoffen auf Tuberkelbakterien und auf einige andere Mikroorganismen. Schweiz. Z. Pathol. Bakteriol. 1950, 13, 729-751.

(29) Hirayama, T.; Fujikawa, F.; Kasahara, T.; Otsuka, M.; Nishida, N.; Mizuno, D. Antitumour activities of some lichen products and their degradation products. Yakugaku Zasshi 1980, 100, 755-759. 